\title{
LAMPIÃO ATRAVÉS DOS CORDEIS: ENTRE O CÉU E O INFERNO
}

\author{
Douglas Augusto da Silva (Autor), Thiago Granja Belieiro (Orientador)
}

Universidade do Oeste Paulista - UNOESTE, Faculdade de Ciências, Letras e Educação - FACLEPP, Licenciatura em História, Presidente Prudente, SP. E-mail: douglassilva_das@hotmail.com.br

\section{RESUMO}

O cangaço foi um movimento armado do nordeste brasileiro que teve seu auge no século XX. Dentre os motivos: miséria, monopólio das terras, brigas de família e a insolência dos coronéis. Podemos classificar estes cangaceiros como "bandidos sociais", vistos como criminosos pela elite e como um herói pelo seu povo. Surgiram vários cangaceiros famosos, porém o mais famoso foi indubitavelmente, Virgulino Ferreira da Silva, o Lampião. Este trabalho tem como objetivo analisar e estudar justamente a literatura de cordel nordestino visando compreender a representação do cangaço. O método se pautará numa pesquisa qualitativa através de uma revisão da bibliografia utilizada e folhetos de cordéis. Os resultados foram sendo vistos ao decorrer do trabalho, quando entendemos a história do cangaço e do cordel, e a sua ligação. Concluímos que os cordéis não querem somente enaltecer a figura de Lampião, mas dessa forma engrandecer a figura do pobre nordestino.

Palavras-chave: cangaço, nordeste, banditismo, Lampião, cordel.

\section{LAMPIÃO THROUGH PAMPHLET LITERATURE: BETWEEN HEAVEN AND HELL}

\begin{abstract}
The banditry was an armed movement in northeastern Brazil that had its heyday in the twentieth century. Among the reasons: poverty, monopoly of lands, family feuds and the insolence of colonels. We can classify these bandits as "social bandits", seen as criminals by the elite and as a hero for his people. There were several famous outlaws, but the most famous was undoubtedly Virgulino Ferreira da Silva, Lampião . This work aims to analyze and precisely study the northeastern line of literature aimed at understanding the representation of the cangaço. The method shall be founded on a qualitative research through a review of the literature and used pamphlet literature. The results were being seen at the course of the work, when we understand the history of banditry and the line, and your connection. We conclude that the strings do not only want to enhance the figure of Lampião but thus magnify the northeastern poor figure.
\end{abstract}

Keywords: cangaço, northeastern, banditism, Lampião, cordel.

\section{INTRODUÇÃO}

Desde muito tempo, podemos perceber a popularidade do movimento do cangaço nordestino e a influência de seus personagens, os famosos cangaceiros, como os do lendário bando de Lampião e Maria Bonita, a Volante que os perseguia, jagunços, coiteiros e etc.

Presente ainda hoje em filmes, em poemas, ou na música popular, como repentes e emboladas, esse movimento permanece na memória do povo, e influencia até hoje, na rica cultura nordestina, que se expande para o resto do Brasil, principalmente com a literatura de cordel, que enaltece a figura do sertanejo nordestino e as aventuras dos cangaceiros, sendo Lampião uma das personagens históricas mais representadas nesta literatura.

Por ser proveniente de uma família nordestina, com uma grande bagagem cultural, sempre estivemos conectados com a cultura nordestina, mais especificamente nesse movimento do cangaço, sempre observando as mais diversas mídias sobre o assunto. A ideia do presente estudo surgiu justamente do interesse nessas histórias do sertão nordestino.

Os principais objetivos deste trabalho são: realizar um breve estudo sobre Lampião e suas histórias no cangaço, estudar brevemente os 
poemas de cordel e seus principais poetas, analisando a literatura de cordel no nordeste brasileiro, com vistas a entender a representação do cangaço, principalmente de Lampião e de seu bando, destacando a importância do movimento na literatura de cordel e na cultura nordestina.

\section{METODOLOGIA}

O método utilizado para se realizar o projeto de pesquisa usará o raciocínio de forma sistêmica para analisar os dados coletados, sendo este o norteador do trabalho, auxiliando nas decisões a serem tomadas, com o intuito de alcançar os objetivos pré-estabelecidos, trazendo assim, o conhecimento válido e verdadeiro.

A pesquisa bibliográfica se realizará a partir de registros decorrentes de pesquisas anteriores, em documentos impressos, como livros, artigos, teses, etc., e principalmente nos diversos poemas que contam as aventuras de Lampião e os cangaceiros.

\section{RESULTADOS}

O Cangaço foi um movimento rebelde de homens armados que se desencadeou do século XIX ao século XX. Como Portela e Bojunga (1982) afirmam, entrar para o cangaço ou para a polícia naquele tempo era o jeito de manter certo nível econômico e conquistar o respeito. Num tempo de miséria geral, o sertanejo era marginalizado, o sertão sofria com secas, desemprego, as terras eram injustamente repartidas e os coronéis, grandes fazendeiros, eram insolentes para com os sertanejos (PORTELA e BOGUNGA, 1982).

Os primeiros bandos independentes possivelmente surgiram durante a grande seca que assolou o nordeste de 1877 a 1879 (DÓRIA, 1982). Já no início do século $X X$, destaca-se o maior nome do cangaço nordestino, o "rei do cangaço" Lampião (PORTELA ; BOJUNGA, 1982).

Virgulino Ferreira da Silva, que mais tarde ficou conhecido como Lampião, possivelmente nasceu no ano de 1900, em Vila-Bela, atual município de Serra Talhada, no Pernambuco. Filho de José Ferreira da Silva e Maria Lopes da Silva, teve mais 4 irmãos e 3 irmãs, família de tropeiros, profissão a qual Virgulino seguiu por algum tempo (PRATA, 1984).

Virgulino e seus irmãos Antonio e Livino, uniram-se a bandos como os de Sinhô Pereira ou de Luiz Padre, e é a morte de seu pai nas mãos da volante que o torna de fato Lampião (Prata, 1984)
Portela e Bogunga (1982) dividem a vida do "Rei do Cangaço" em duas fases: quando Virgulino assume o comando do bando na década de 1920, numa fase de um Lampião impulsivo, sedento por vingança. Durante essa época Lampião perde o olho direito e seus irmãos acabam morrendo, Livino em 1922 e Antonio em 1927; já na segunda fase há a integração das mulheres no grupo, nos anos 1930, quando Lampião se encontra com Maria Bonita, numa fase mais humanizada do grupo, com um Lampião mais maduro.

Em junho de 1938, uma tropa entrou no esconderijo em Angicos, matando e decapitando Lampião, Maria Bonita e mais nove cangaceiros. Suas cabeças foram colocadas como prêmios em museus no nordeste (DÓRIA, 1982).

Apesar de sua inexistência nos dias atuais, o cangaço, ainda continua vivo na memória popular, são inúmeras suas representações como em filmes, livros, músicas, etc., mas principalmente na literatura de cordel.

De acordo com Haurélio (2010), a Literatura de Cordel chegou ao Brasil a bordo das primeiras caravelas portuguesas. "É próprio do homem, em seu constante deslocamento geográfico, levar consigo, além dos conhecimentos que the garantam a sobrevivência, a sua cultura" (HAURÉLIO, 2010, p. 13). Concordando com Andrade (2013), no Nordeste, o cordel encontrou um ambiente extremamente propício para o seu desenvolvimento: uma população com costumes e cultura rural, e predomínio praticamente absoluto da comunicação oral, e com a valorização das feiras livres e das feiras tradicionais, onde acontecia o encontro da comunidade, veio junto a grande valorização dos poetas e cantadores, que transformavam suas apresentações em verdadeiros espetáculos (ANDRADE, 2013).

A cultura dos cordéis cantados pelos "medajs" muçulmanos uniu-se a da cultura portuguesa, confirmado por Andrade (2013), ao relatar que os brasileiros, como os portugueses, conservaram dos muçulmanos, o seu modo de apresentação e a sua fidelidade aos instrumentos, como a rabeca, pandeiro ou viola, usados principalmente por repentistas e emboladores nordestinos até os dias atuais. Como coloca Haurélio (2010), o cordelista brasileiro, nada mais é do que um descendente do menestrel errante medieval, que por sua vez descende do rapsodo grego, portanto, a 
Literatura de Cordel é sem dúvidas um cruzamento de culturas populares durante os séculos.

\section{DISCUSSÃO}

O questionamento de para onde Virgulino foi após a morte, é um dos principais temas dos cordéis, com certeza devido a religiosidade presente no povo nordestino, dando luz a grande criatividade de poetas e cantadores. Dentre estes poetas podemos citar José Pacheco, em seu cordel (possivelmente o mais famoso sobre Lampião), "A Chegada de Lampião no Inferno". Ao analisarmos primeiramente ao titulo, podemos notar a opinião do autor sobre Lampião, possivelmente um bandido maligno.

$$
\begin{aligned}
& \text { [...] } \\
& \text { Um cabra de Lampião } \\
& \text { por nome Pilão Deitado } \\
& \text { que morreu numa trincheira } \\
& \text { um certo tempo passado } \\
& \text { agora pelo sertão } \\
& \text { anda correndo visão } \\
& \text { fazendo malassombrado } \\
& \text { [...] }
\end{aligned}
$$

Logo de início do cordel de Pacheco, já nos damos de cara com um outro cangaceiro já morto, Pilão Deitado, antigo cabra de Lampião, que agora é uma assombração no sertão.

[...]

E foi quem trouxe a notícia

que viu Lampião chegar

o inferno nesse dia

faltou pouco pra virar

incendiou-se o mercado

morreu tanto cão queimado

que faz pena até contar.

$[\ldots]$

Acima podemos analisar que o cordelista, embora ainda veja Lampião como um indivíduo do mal, ainda o vê como um sujeito de alta periculosidade e de enorme valentia, que ao dizer que "morreu tanto cão queimado", ele se refere sem dúvidas aos demônios, o que se confirma nas estrofes a seguir:

\section{[...]}

Morreu a mãe de canguinha

e pai de forrobodó

cem netos de parafuso

um cão chamado cotó

escapuliu boca ensôça

e uma moleca moça quase queimava o totó

\author{
Morreram cem negros velhos \\ que não trabalhavam mais \\ um cão chamado traz cá, \\ vira-volta e capataz, \\ tromba suja e bigodeira \\ um cão chamado goteira \\ cunhado de satanás \\ [...]
}

Portanto, mesmo na pós-morte, o famigerado cangaceiro Lampião, ainda é um homem sem medo, que não teme sequer os demônios do inferno. Em outros versos, Pacheco mostra a conversa do vigia dos portões do inferno e o próprio Satanás, onde nem ele aceita a entrada do bandido:

$[\ldots]$

_Não senhor, satanás disse

vá dizer que vá embora

só me chega gente ruim

eu ando muito caipora

eu já estou com vontade

de botar mais da metade

dos que tem aqui pra fora

[...]

[...]

_Leve cem dúzias de negros

entre homem e mulher

vá na loja de terragem

tire as armas que quiser

é bom avisar também

pra vir os negros que tem

mais compadre Lucifer

[...]

Pacheco conta que Lampião não se rendeu aos diversos demônios, utilizando de suas antigas táticas de guerra de quando era vivo, e nos versos abaixo podemos perceber a grande resistência e a demasiada persistência, além é claro do preparo físico de Virgulino nos momentos de briga, algo que se confirma ao analisarmos o passado do Capitão.
[...]
Estava travada a luta
mais de uma hora fazia
a poeira cobria tudo
negro embolava e gemia
porém Lampeão ferido
ainda não tinha sido
devido a grande energia 


\section{$[\ldots]$}

Ao final do cordel, Pacheco coloca Lampião como vencedor e conta que o mesmo não ficou no inferno e nem mesmo no céu o aceitaram, e relata que provavelmente sua alma pena no sertão até hoje.

Se pararmos para analisar o cordel "O encontro de Lampião com o Padre Cícero no Céu", do trovador Minelvino Francisco Silva, podemos ver uma certa continuação não-oficial do cordel anterior, que se inicia na briga de Lampião contra os demônios no inferno, observando isto já nas primeiras estrofes:

[...]

Lampião chegou no inferno

Botou mesmo pra quebrar

Deu porrada no porteiro

Por não deixar ele entrar

Ali começou uma luta

De fazer admirar

[...]

\section{$[\ldots]$}

Lampião foi pra o sertão

Mas para a surpresa dele

Ele via todo povo

E o povo não via ele

Pôs ele se encabular

Com um negócio daquele

$[\ldots]$

Ao perceber que ninguém mais o reconhecia no seu amado sertão, local onde um dia ficara conhecido como "Rei", a tristeza tomou conta e logo viu que já não era o mesmo, ele agora se dava conta de sua morte:

[...]

Disse ele: agora sim

O que eu devo fazer?

Eu pensei que estava vivo

Que nunca ia morrer

Acreditei que estou morto

Sem ter pra onde esconder

[...]

Minelvino neste cordel mostra sem dúvidas um Lampião arrependido, e mostra uma outra faceta do capitão, deixando claro a sua religiosidade, e sua admiração e adoração ao Padre Cícero, visto como santo até hoje no nordeste, no qual Lampião se apóia em busca de ajuda:

$[\ldots]$
Meu padrinho Padre Cícero

Passou a vida a rezar, Já eu fui muito ao contrário

Passei a vida a matar

Mais ele pode pedir

A Deus pra me perdoar

$[\ldots]$

Lampião depois de sua reza ao seu louvado padrinho vê descer uma grande escada com destino para o céu, e procurando seu padrinho chegou na porta do céu, quando avistou São Pedro:

[...]

Sou eu difato, meu santo

Que vivi na escuridão

Só me confiando em arma

Para matar meu irmão,

Eu quero ver meu padrinho

O Padre Cícero Romão

[...]

Minelvino conta que São Pedro depressa chama Padre Cícero Romão, para quem Lampião, banhado em prantos, implora o perdão:

[...]

Meu padrinho Padre Cícero

Agora me arrependi

Porque vim ter a certeza

Que lá na terra eu morri

E vim pedir ao senhor

Pra ficar consigo aqui

[...]

Nos seguintes versos fica evidente a enorme religiosidade cristã do autor, mostrando toda sua admiração ao Jesus Cristo, figura principal do catolicismo:

[...]

Padre Cícero respondeu:

Não sou eu que sou a luz

Eu apenas lá na terra

Conduzi a minha cruz

Só quem pode te salvar

É o Santo Mestre Jesus

$[\ldots]$

O santo nordestino leva o cangaceiro até ao seu julgamento, ao encontro do todo poderoso Senhor e do seu acusador Satanás, porém o mesmo já estava todo espancado devido a briga com Lampião e não apareceu no julgamento:

[...] 
Depois disse o Bom Jesus

Eu fui nascer em Belém

Pra salvar o pecador

Não para acusar ninguém

Se ninguém te acusou

Eu não acuso também

$[\ldots]$

Podemos perceber, portanto, que o autor, sendo religioso, acredita na redenção dos homens através do arrependimento dos pecados, sendo todo seu catolicismo, assim como o de Lampião, na estrofe abaixo:

[...]

Lampião naquele instante

Deu um pulo de alegria

Dizendo: bendito seja

O Nosso Deus que nos cria

O Padre Cícero Romão

E a Santa Virgem Maria

[...]

\section{CONCLUSÃO}

Como podemos perceber ao decorrer do estudo, Lampião, seu bando e todos os personagens que fizeram parte do cangaço, são de demasiada importância para o imaginário nordestino e a cultura popular, não só nordestina, mas também de todo o Brasil. Mesmo sendo uma forma de banditismo, o cangaço ganhou fama nacional, sendo hoje alvo de pesquisas, devido a enorme curiosidade em um movimento que perdurou por séculos.

Devido as suas diversas ambiguidades e interpretações de sua história, Lampião, tornouse alvo dos mais diversos olhares, não só historiográficos, como também caiu na graça dos famosos trovadores do nordeste.

Ao decorrer da análise podemos perceber presente a ideia das "representações sociais" estudada por Chartier, confirmando sua hipótese de a representação vai depender do contexto em que o representador (neste caso, o cordelista) estará inserido e sem duvidas é sempre ligada a interesses pessoais.

Quanto as histórias contadas sobre sua pós-morte, podemos perceber que enquanto uns afirmam sua ida ao inferno, outros acreditam na sua redenção e ida para o céu.

Todavia, mesmo com todas essas ambiguidades e este eterno questionamento, se o capitão tratava-se de um herói ou de um bandido, conseguimos analisar uma semelhança em todos os poemas sobre Lampião, ele é sempre retratado como um homem resistente, bravo, destemido, sem medo, um verdadeiro "cabra-macho", como diria os regionais.

Assim, podemos concluir, de fato, que os cordéis que retratam as mais variadas aventuras de Lampião, não quer somente enaltecer a figura do mesmo, mas principalmente, engrandecer a figura do pobre nordestino, criando uma espécie de representante do povo, criando um verdadeiro ícone, um herói do povo nordestino.

\section{REFERÊNCIAS}

ANDRADE, C. H. S. Corda, Cordel, Cordão. In: SILVA, J. M. F.; BARROS, L. G.; ASSARÉ, P.. Feira de Versos: Poesia de cordel. São Paulo: . Ática, 2013. ..

CHARTIER, R. A História Cultural: entre práticas e representações. 2. ed. São Paulo: Difel, ano ???

DÓRIA, C. A.. O Cangaço. 3. ed. São Paulo: . Brasiliense, 1982. .

HAURÉLIO, M.. Breve história da literatura de cordel. .São Paulo: Claridade, 2010.

PACHECO, J. A chegada de Lampião no inferno. [s.n.]. [S.I.: s.n.], [199 -?].

PORTELA, F.; BOJUNGA, C. Lampião, o cangaceiro e o outro. São Paulo: Traço, 1982.

PRATA, R. Lampião. São Paulo, Traço s/d.

SILVA, M. F.. O Encontro de Lampião com Padre

Cícero no Céu. [s.n.]. [S.I.: s.n.], [199 -?].

Recebido para publicação em 23/08/2016

Revisado em24/08/2016

Aceito em 06/09/2016 